\title{
HUMANITY'S TRYST IN DECIPHERING MARRIAGES FROM MYTHOLOGY: BRAIDING LITERATURE AND
} \section{ART}

\author{
Anasuya Adhikari ${ }^{1}$, Dr. Birbal Saha ${ }^{2}$ \\ ${ }^{1}$ Research Scholar, Department of Education, Sidho-Kanho-Birsha University, Purulia, West Bengal, \\ India \\ ${ }^{2 *}$ Professor, Department of Education, Sidho-Kanho-Birsha University,Purulia, West Bengal, India
}

Corresponding Author: Dr. Birbal Saha, Professor,Department of Education, Sidho-Kanho-Birsha University, P.O. Sainik School, Ranchi Road, Dist. Purulia, West Bengal,

Article DOI: $\underline{\text { https://doi.org/10.36713/epra8927 }}$ DOI No: 10.36713/epra8927

\begin{abstract}
Studying Anthropology of Art has been a matter of long-term qualitative research studied under Cultural Anthropology. Understanding Anthropology of Art is therefore something which involves transcending over the regimented boundaries of culture and art. Entering this complex process of interpreting anthropological aspects, we delved deep into the context and examination of Indian art and iconography. Our heritage has evidently focused very strongly on the meaningfulness of art to society, interpreting human cognition into a concrete order. The depiction of the divine union of Shiva-Parvati, is thematically represented extensively in Indian sculpture art. Regrettably, this very fascinating matter did not receive a very comprehensive consideration so far. Our purpose for undertaking this analysis is to reckon wisdom of the extant of incorporating mythological culture and rituals into present human society, diverse expressions of art, associated with different age and time period, all with a single awe-inspiring theme- The Marriage of Shiva and Parvati. Thereafter, keeping in mind the textual references available, we have kept ourselves restricted to the study, strictly coinciding with the theme depicted in Indian sculpture. Indian art has an immense affinity towards mythology and depiction of the events in a cosmic scale. Indian temple sculpture is a celebration of the divine ceremonies. Doing this, we find relevant textual interpretations and references from Kalidas' Kumarasambhava, an epic recounting the events leading to the 'Kalyanasundara'- the iconographical depiction of the wedding rites of Shiva and Parvati and the birth of Kartika, making the art study an extension of literary apotheosis.
\end{abstract}

KEYWORDS: Anthropology of Art, Cultural Anthropology, Indian Art and Sculpture, Kumarsambhava

\section{INTRODUCTION - THE BEAUTY AND DIVINITY IN SCULPTURES}

Cultural Anthropology is incomplete without understanding the concerns of the 'universality of art'. Notable anthropologists came to a conclusion that the categorization of the West relating to 'sculpture', 'painting' or 'literature', which is conceived as independent artistic genres, do not actually exist in a significantly different or individualised form (Layton, 1981). Forms of art are nothing but the concretion of human imagination into a form and structure, which definitely has to be interlinked to the other forms of art, specifically to that of literature. Be it European Renaissance to the Indian Independence movement, all historical movements was a parallel movement in both art and literature. Sculpture has not only been a pleasant source of delight but also favoured medium of artistic expression in India. Indian architectures were extensively embellished with them and undoubtedly, their presence are interwoven. The Indian sculpture 
consisted of the subject matter which was perpetually preoccupied mortal forms which were practices to tutor people with the solitary truths of the Hindu, Jains or Buddhist. According to Herbert Reed, "it is certain mathematical proportions which gives rise to that emotion in us which we normally associate with works of art." The nude delineation were used to represent both for the body- symbolising spirit and also to confirm the fancied shapes of the divine figures.

The works of art produced throughout the human history in any form associate with the beauty of women or studying the 'aesthetic form'. In fact, the form of art becomes pleasurable only when it is associated with beauty. Will Durant exclaims, "the beautiful is primarily that which is sexually desired; and if other things are beautiful to us it is derivatively, and by ultimate relationship with the original fount of the aesthetic sense." The sense of individuality is absent in the Indian sculpture, which makes it a perfect example and area of study for the art anthropologists. The reason might be deemed as the figures are assumed to be of shapes which are more in symmetry or possess perfectness and ultimate than anything to be raised in the slightly transitory display of human models. Aristotle defines beauty as, "symmetry, proportion, and an organic order of parts in a united whole." The presence of multiple heads and limbs of the sculptured Hindu deities were thought to be a necessity to display the presence of the power attributes and manifestations. Kalidas in Kumarasambhava pens the absolute need of a perfect symmetry in the physical appearance of Parvati (translated);

"Her body, charming in its perfect symmetry was unfolded (developed) by fresh youth like a painting gradually growing under the brush (of a painter),

or like a lotus blooming under the (influence of the) rays of the sun"

\section{-- (Kumarasambhava, Canto I- L.32)}

Here, Kalidas closely analyses the 'Creator's' urge to create a perfect aesthetic embodiment of Parvati (translated);

"The Creator, after he had fashioned her beautiful thighs, not very long, rounded and symmetrical, had to make an effort, as it were, for the production of excellent beauty when forming her other limbs."

-- (Kumarasambhava, Canto I- L.35)

\section{KALYANASUNDARAAND PANIGRAHANA}

Human tendency to remain engulfed into social groups makes him enter into the institution of marriage. Mythology, art, literature shows how these set of social values can be idealised and hence presented through the stories of the divine. Both the sculptures and literature represents "the differentiation of the Absolute into antagonistic yet co-operative pairs of opposites." (Zimmer, 1946, p.137) Just like the most usual and oldest forms of, Shiva and Parvati- collectively known as ShivaShakti is based on the duality of the sexes. The Kalyanasundara episode or the marriage of Shiva and Parvati is a majestic theme depicted in the sculptures which adorns the temples of India. Thereafter, the figures and images displaying the theme came to be regarded as the Kalyanasundara Murti. The etymology of the word 'Kalyana' intrinsically means 'auspiciousness' or 'welfare'. But most aptly used in the 'pious sense of marriage', particularly that of of Shiva. This marriage was not only divinely appreciable but also most desired and cherished, since the marriage was destined to give birth to Kumar, who was fated to destroy Taraka, the evil. The couple exemplified supreme beauty and cosmic union.

Another ritual 'Panigrahana' or 'The Hand Giving Ceremony' is also a predominant theme in the sculptures. They are presented in a series, where the depiction features a story. Indian art features intricate monumental interest from images to stories carved delicately into the stone walls of the temples, bearing a testimony of an enriched mythology. This symbolism is something which shows its ubiquitous presence in the temples. Every life principle, be it pursuit of joy, depiction of sex, emotional pleasure and connection are merged into erotic, mystical and architectural forms in the Indian temples. The Hindu texts like Upanishads, provide motifs and doctrine of mortal life. The Indian temples express these doctrines in a different style, by way of art and spaces. Taking, Brihadaranyaka Upanisad, it recites-

"In the embrace of his beloved a man forgets the whole world, everything both within and without; in the same way, he who embraces the Self, knows neither within nor without." (Brihadaranyaka Upanishad, 4.3.21)

\section{TEXTUAL SOURCES: KUMARASAMBHAVA AND THE THEME OF MARRIAGE}

Literary anthropologists play a key role in exploration of the role played by literature in forming, cultivating or assembling social life and 
individual experience, in a specifically provided cultural, social and historical settings. Similarly, the iconographic study could not have been complete without the study of the literary texts. The events and representation in the panels and images can be well understood under the lens of literary interpretations. Doing this the best possible references can be drawn from Shivapurana, Kalipurana and Upanishads. But our theme finds its best relevance with Kalidas' Kumarasambhava. We can absolutely grace the phenomenal glimpse of the artistic interpretation of the sculptors at par with this theme. The delicate movements, expressions and feelings are so well imagined and penned, as if the events are been visualised as a flick. The present paper is an attempt to connect and reconstruct mythology through the artistic aspects and to that of literature.

Kumarasambhava elaborates the birth of Parvati, her wedding to Shiva and the birth of a probable son, Kartikaya ('Kumar'-son; 'Sambhava'probable birth of son). The artists must have depended extensively on these age-old texts while drawing the necessary and detailed observations related to their artistic language and expressions elaborated through the theme. At the same time, very frequently correlated their own artistic imagination by adding or removing any details suiting their own understanding related to social institution of marriage. Marriage is considered to be one among the ten important sacraments (Samskara) of mortal beings. Marriage strengthens human bond at the same time an essential social custom for regenerating next generation. Henceforth, this scene appeals much more than the epic war scenes. There is an attempt through the descriptions, to identify the particular aspects of marriage and the related events as represented in the sculpture.

\section{THE CONCEPT OF CREATION AND POET, THE ULTIMATE CREATOR}

Kalidas voices the Creator in the beginning of the text when $\mathrm{He}$ is creating Parvati. The poet strictly emphasises on the 'perfectness', 'symmetry' and deploys all the possible aesthetic senses to perceive her beauty. Kumarasambhava quotes:

"In short she was created by the

Creator of the universe with great effort, as if with a desire to see all beauty combines in one form, by gathering together all the standards of comparison and placing them, each in its place."

--(Cantos I, L.49)

Here Kalidas probably identifies with the idea of Creationism, which manifests that every living or non-living identity is created by a Supreme Creator, possessing divine power. What the poet does here is voicing the Creator while creating his best divine figure. Interestingly the poet hitherto, turns to be the 'creator of the creator' and contributes to the process of creation, depicting the creator in his text. He gives birth to the Creator, who in turn creates the divine. Thus, the identity of the creator is here the poet in the text, and the sculptor in the panels. The major attribute of the Creator here is an entity concerned with structuring, employing symmetry and very much concerned with aesthetics. All these are probably, complete human formation and imagination along with the concept of the presence of the supreme being- the Creator. The poet is thereafter the ultimate, playing the role of creating Hominidae,

"Thou knowest thyself in thyself, thou created thyself by thyself, and thou art absorbed in thyself by thy own mighty self." --(Cantos II, L.10)

The poet and the sculptor gives shape to the 'unknown' or 'unfigured' identities. And that is how they turn to be the supreme creators.

\section{KALYANASUNDARA DEPICTED IN INDIAN TEMPLES WITH INTERPRETATIONS FROM 'KUMARSAMBHAVA'}

The anthropology of emotion is found to be an area of interest among the anthropologists and marked extensively by several influential reviews and essays. Lutz and White (1986) went on to organize the authors' synthesis dwelling around the tension between the relativists and universalist approaches, which turns out to be a plea for further studies of cultural understandings of emotion. Emotions are best displayed in any form of art, and hence it becomes necessary to dilute oneself into the medium of art to absorb the emotions displayed, collaborated along with rituals, customs and traditions. Indian temple sculpture he one such instance to exemplify the same:

1. Ellora Caves- With Special Reference to Kailash Temple (Cave 16) and Rameshwar Cave (Cave 21)

Build in around the $8^{\text {th }}$ Century, the Ellora Cave is the largest of the rock-cut monastery temple. Along with many spectacular iconography, the Rameshwara Cave, and Kailash Temple are the most remarkable. The Kailash Temple illustrates the theme of human emotions and sentiments. Shiva is seen bearing four hands, where the principal hand holds the right hand of Parvati. This details the Hindu marriage ritual of Panigrahana. Kalidas illustriously quotes in Kumarasambhava the beauty of the union 


\section{SJIF Impact Factor 2021: 8.013| ISI I.F.Value:1.241| Journal DOI: 10.36713/epra2016 ISSN: 2455-7838(Online) EPRA International Journal of Research and Development (IJRD) Volume: 6 | Issue: 11 | November 2021 \\ - Peer Reviewed Journal}

between Shiva and Parvati through the ritual of Panigrahana:

"Being united with her beauty of whose moon-like face was heightened, like the world with the autumnal season, the beauty of whose face, the moon, is increased. Shiva had the lotuses of his eyes expanded like water rendered clear (delighted)."

--(Cantos VII, L.74)

The Rameshwara Temple features Shiva and Parvati standing cordially on a platform, performing the rituals of marriage. The figure shows Shiva standing Sampadasthanaka, performing the rite of Ehnigrahana in Hindu marriage. Shiva's figure is simply carved. An elaborate iatamukuta and a sacred thread are very clear. The other ornaments are very few except the prominent Karnakundalas. Kalidas inextricably lines out the clear imagery of the events through these lines:

"Brahmana (the priest) said to the Bride, "Dear Child, this fire is the witness to the conclusion of your marriage rite: practise righteousness with Shiva, your husband, giving up argumentation (i.e., with implicit acquiescence)."

\section{--(Cantos VII, L.83)}

The sculptures of the Ellora temple are depiction of Shivapurana, the original source of Kumarasambhava. The ritualistic descriptions are vivid and unique attributing the Indian aesthetics. It is much more than mere attribution. The inclusion of bhakti, not restrain it into the realm of Stotras, but to another dimension of the application and perception of the Rasas.

\section{Elephanta Caves, Maharastra}

The age old collection of cave temples depicts Shiva in various forms. There is syncretism of Buddhist and Hindu ideas and iconography in the cave sculptures. Dating between 5th-9th Century, the caves are composed of solid basalt rock and presently much of the sculptures are mutilated. The ruins presently are not only a scholarly study for the students of Fine Arts, but also largely for Religious Study, Buddhist Study, Archaeological or even purely historical. The Cave 1 (The Main Great Cave) shows various forms of Shiva- Shiv, Shakti (Ardhanarishwar) and Rudra in various events, among which again splits into the Gunas- Satva, Rajas and Tamas, the most dominating and fascinating is the Kalyanasundara Episode. Kumarsambhava states:

"Salutation of thee three forms, the one soul before the creation of the world, who afterwards divides itself into

-- (Canto II, L.4)

manifestedst a variety (of forms)."

R.Von Leydon quotes "a great advance in vision and conception has been achieved in the Kalyana Sundara murti panel." The panel shows a crowded composition centered with the main dietiesShiva and Parvati. The background presents smaller figures. The horizontal division in the panel is represented by the stylised rocks or cloud motifs, presenting Shiva's large halo. Shiva, as well as Parvati, very well proportioned, stands in a subtle tribhanga. The karna-kundalas, sacred thread, Sarpavalavas are well portrayed. The divine couple is seen with calm and happy expressions. The presence of Brahma, the officiating priest is well elaborated. The panel is badly mutilated, thereafter total identifications is challenging. The panel's upper part is crowded.

Of all the panels accessible and decipherable of Kalyanasundara, this particular piece produces the most powerful representation of the theme. The Tribhanga posture is very frequently used in Indian art and is very well linked to the Rasas. Kalidasa particularly was much inclined to the Rasas. Therefore, the scene elaborated here showing the glory of love achievement, coyness and emotional subtleness, becomes a very contemporary theme which was used both by Kalidasa in his literary masterpiece Kumarasambhava at par with sculptors' aesthetic imaginations. He frequently hints at the treatment of Rasas collaborating the Creator's achievement in creating His masterpiece:

"Male and Female are separate manifestation of thy own self, (thus) split up through the desire of creating; and these are declared as the parents of the creation that sprang into
-- (Canto II, L.7)

\section{Khajurajo- With Reference to Khandaria Mahavev Temple}

This $10^{\text {th }}$ century temple niche is present in the central sanctum of the Kandariya Mahadeva Temple, Khajuraho. Shiva and Parvati's position is shown in a partially broken panel located under the marriage mandapa. The twin pillars are projected with floral designs. Rows of mangalaghatakas or ('auspicious wedding vase') are present. The cloud like structures are designed to install the venue for the theme. There is a presence of two figures in the background, that of a male and a female. These might be Vishnu and Lakshmi pictured by Parvati's side, while Himavan and Mena by Shiva's side. This presence is texted in the early texts like Shivapurana and Kalipurana. the three Gunas (Satva, Rajas, Tamas) and 


\section{SJIF Impact Factor 2021: 8.013| ISI I.F.Value:1.241| Journal DOI: 10.36713/epra2016 ISSN: 2455-7838(Online) EPRA International Journal of Research and Development (IJRD) Volume: 6 | Issue: 11 | November 2021 \\ - Peer Reviewed Journal}

Similar interpretations has been majestically detailed by Kalidas in Kumarsambhava:

"While the sage was speaking thus, Parvati, who was by her father's side, counted the petals of her supportive lotus with a down-cast look."

--(Cantos VI, L.84)

Kalidas illustrates a beautiful picture, just the same way as the scene is pictured in the sculpture. He talks about the piousness of the Muhurata, the wedding moment. He wraps intricately the mythological aspects with that of his literary skills, which further finds a place in the symmetrically cast, grandiose sculpture.

"At the Muhurata (period of 48 minutes) auspiciously presided over by the

Sun when the Moon was in conjunction with the Uttarfalguni (its $12^{\text {th }}$

Mausion), the kinswomen with their husbands and male children living put

-- (Canto VII, L.6)

\section{CONCLUSION}

The artists depicting the theme of the marriage of Shiva and Parvati seem to have been very familiar not only with the iconography and mythology pertaining to the divine episode, put they seem to be well conversant with the various important rites of marriage, which makes it a very apt theme of anthropological studies. The depictions not only reveal the amount of knowledge that they had, but also the power of their expression of the ideas and emotions in the most effective aesthetic forms. The four major subfields within anthropology are linguistic and literary anthropology, socio-cultural anthropology, archaeology (including the study of sculptures), and physical anthropology. All of these subfields takes a different notion and approach to the study of humans; but when together and interlinked, they provide a holistic view. It seems that the artists have endeavoured to give expression to the idea of the primordial unity between the male and the female principles through the representations of the theme of the marriage of Shiva and Parvati, while Kalidas methodically expressed and stylised the concept in the pages of the epic 'Kumarasambhava'. Indian art has been a gamut of these exposures, conceptualising aesthetics, harmonizing rhythm, balancing soothing agreement between mythology and art and giving shapes to the 'unknown.'

\section{REFERENCES}

1. Banerjea, J.V. (1956). The Development of Hindu Iconography Calcutta.

2. Chandra, P. (1985). The Sculpture of India 3000 B.C. - 1300 A.D. Washington.

3. Danielou, A. (1999). The Hindu Temple, Inner Traditions, Rochester, Vermont.

4. Dhar, P.P. (2011). Indian Art History: Changing Perspective, D. K. Printworld (P) Ltd. and New Delhi National Museum Institute New Delhi.

5. G. Angioni, (2011). Fare dire sentire: l'identico e il diverso nelle culture, Nuoro, il Maestrale.

6. Gell, Alfred. (1998), Art and Agency: An Anthropological Theory of Art. Oxford: Oxford University Press ISBN 0-19-828014-9

7. Geertz, C. (1988). Works and lives: The anthropologist as author. Cambridge, UK: Polity.

8. Gopal, R. (1984). Kalidasaa: His Art and Culture, Concept Publishing Company.

9. Hatcher, E. P. (1985). Art As Culture: An Introduction to the Anthropology of Art. Lanham: University Press of America ISBN 0-89789-628-9

10. Howard, M. \& Morgan, P. (2006) Introduction, in The Anthropology of Art: A Reader.

11. Howard, M. (2009). Art as a Mode of Action: Some Problems with Gell's Art and Agency. Journal of Material Culture, 14 (1): 5-27

12. Hymes, D. (1973). An ethnographic perspective. In Special issue: What is literature? New Literary History, 5.1: 431-457.

13. Javed, A. and Javeed, T. (2008). World Heritage Monuments and related edifices in India, Algora Ppublishing, NY.

14. Kalidas and Heifetz, H. (Translated). (2015). Kumarsambhavam, Penguin Books Limited.

15. Layton, R. (1981). The Anthropology of Art. Cambridge: Cambridge University Press ISBN 978-0521-36894-0

16. Leavitt, J. (1996). Meaning and feeling in the anthropology of emotions. American Ethnologist, 23.3: 514-539.

17. Lutz, C, and Geoffrey M. W. (1986). The anthropology of emotions. Annual Review of Anthropology, 15:405436.

18. Mookerjee, A. (1966). From Prehistoric to Modern Times: The Arts of India. Charles E. Tuttle Co. Publisher. Rutland, Vermont.

19. Pal, P. (1986). Indian Sculpture Vol I. Los Angeles Country Museum of Art, University of California Press, Berkeley, Los Angeles and London.

20. Ross, B. (2004) A Critique of Alfred Gell on Art and Agency. Oceania.

21. Robert H. L. (2003). Art and Agency: A reassessment. Journal of the Royal Anthropological Institute.

22. Schwartz, S.L. (2008). Rasa: Performing the Divine in India.

23. Singh, U. (1993). Kings, Brahmanas and Temples in Orissa: An Epigraphic Study AD 300-1147. Munshiram Manoharlal Publishing Pvt. Ltd. New Delhi.

24. Strathern, M. (1987). Out of context: The persuasive fictions of anthropology. Current Anthropology, 28.3: 251-281. 
SJIF Impact Factor 2021: 8.013| ISI I.F.Value:1.241| Journal DOI: 10.36713/epra2016 ISSN: 2455-7838(Online) EPRA International Journal of Research and Development (IJRD) Volume: 6 | Issue: 11 | November 2021

- Peer Reviewed Journal

25. Sivaramamurti, C. (1977), The Art of India, New York.

26. Sthapati, G. (2002). Indian Sculpture and Iconography, Forms and Measurements, Sri Aurobindo Institute of Research in Social Science, Pondicherry.

27. Varadpande, M.L (2006), Woman In Indian Sculpture, Abhinava Publications, Delhi.

28. Zimmer, H. (1946). Myths and symbols in Indian Art and Civilization, Pantheon Books, Washington D.C

Translation and quotes are taken from:

1. Kumarasambhava Cantos I-VII (1917)- Sanskrit Commentary, English Translation \& Notes - MR Kale, Standard Publishing, Bombay. 